\title{
Pengurusan Surat Model Hibrid: Pemanfaatan Aplikasi e-Surat dalam Pengurusan Di Dinas Kearsipan dan Perpustakaan Propinsi Jawa Tengah
}

\author{
${ }^{1}$ Eristi Dwi Al Mubarak, ${ }^{2}$ Dyah Tri Wulansari \\ ${ }^{1}$ Badan Nasional Penanggulangan Bencana RI \\ ${ }^{2}$ Dinas Kearsipan dan Perpustakaan Provinsi Jawa Tengah
}

\section{ABSTRACT}

This article examines the hybrid model of mail handling carried out by the Archives and Libraries of Central Java Province. Management using the eSurat application was developed to facilitate the management and distribution of incoming and outgoing mail, besides that there is also a reference for uniformity in managing incoming and outgoing mail automatically. Despite utilizing the e-Surat application in mail handling. Dinarpus Central Java still carries out conventional mail management activities such as receiving, checking, disposing and signatures. Analytical descriptive method is used in describing the object being studied. Data collection used three methods, namely, participatory observation, interviews and literature study. Participatory observation was carried out through direct observation and practice of letter handling activities at Dinarpus Central Java. Interviews aim to obtain information through sources who are directly involved in mail handling activities using the eSurat application. Literature study is a technique of collecting data from various library materials to strengthen the analysis and exposure conducted by the author. The use of e-Surat applications in management activities at Dinarpus Central Java is a hybrid model of letter management that combines electronic and conventional letter management. The e-Mail application has a significant impact on the smooth running of mail management activities, both in handling incoming and outgoing mail. This shows that the features contained in the e-Surat application have not been fully used because they are still constrained by regulations on the development stage being carried out by Dinarpus Central Java.

\section{INTISARI}

Artikel ini mengkaji tetang pengurusan surat model hibrid yang dilakukan oleh Dinas Kearsipan dan Perpustakaan Provinsi Jawa Tengah. Pengurusan dengan menggunakan aplikasi e-Surat dikembangkan untuk mempermudah manajemen dan pendistribusian surat masuk dan surat keluar, selain itu juga agar terdapat acuan keseragaman dalam pengelolaan surat masuk dan surat keluar secara otomasi. Meskipun memanfaatkan aplikasi e-Surat dalam pengurusan surat tetapi Dinarpus Jateng tetap melakukan aktivitas pengurusan surat secara konvensional seperti penerimaan, pengecekan, disposisi dan tanda tangan. Metode deskriptif analitis digunakan dalam menggambarkan objek yang dikaji. Pengumpulan data menggunakan tiga metode yaitu, observasi partisipatif, wawancara dan studi pustaka. Observasi partisipatif dilakukan melalui dengan pengamatan dan praktik secara langsung aktivitas pengurusan surat di Dinarpus Jateng. Wawancara bertujuan untuk memperoleh keterangan melalui narasumber terlibat langsung dalam aktivitas pengurusan surat memanfaatkan aplikasi e-Surat. Studi pustaka merupakan teknik pengumpulan data dari berbagai bahan pustaka untuk memperkuat analisis dan paparan yang dilakukan penulis. Pemanfaatan aplikasi e-Surat dalam aktivitas pengurusan di Dinarpus Jateng merupakan pengurusan surat model hibrid yang menggabungkan pengurusan surat elektonik dan konvensional. Aplikasi e-Surat memberikan dampak yang cukup signifikan dalam kelancaran kegiatan pengurusan surat, baik pengurusan surat masuk maupun surat keluar. Hal tersebut menunjukkan bahwa fitur yang terdapat dalam aplikasi e-Surat belum digunakan sepenuhnya karena masih terkendala oleh peraturan tahap pengembangan yang sedang dilakukan oleh Dinarpus Jateng. 


\section{PENDAHULUAN}

Komunikasi adalah suatu hal yang sulit untuk dapat dihindari dalam kehidupan sehari-hari, utamanya di organisasi. Komunikasi berperan penting untuk menunjang kerjasama didalam sebuah organisasi, sehingga arah organisasi dapat ditentukan sesuai dengan rencana awal. Graber (2003: 2) berpendapat bahwa:

"Members of organizations communicate because they must receive and transmit information to coordinate their activities and perform their jobs. Messages are intended to change the receive's knowledge, attitude or overt behavior in some predertemined manner."

Personil organisasi berkomunikasi sebab mereka harus menerima dan mengirimkan informasi dengan tujuan mengoordinasikan kegiatan dan melaksanakan pekerjaan. Pesan tersebut dimaksudkan mengubah pengetahuan, sikap, atau perilaku dari si penerima dengan cara-cara yang telah ditentukan sebelumnya. Graber (2003: 2) menjelaskan bahwa komunikasi di organisasi telah menjadi kebutuhan setiap orang yang terlibat dalam organisasi. Hal ini karena dalam organisasi umumnya memiliki tujuan yang harus dicapai melalui koordinasi yang dilakukan secara bersamaan. Komunikasi tersebut diharapkan mampu menghasilkan suatu tindakan yaitu kerjasama untuk mencapai tujuan yang sebelumnya telah direncanakan.

Pada lingkup organisasi, komunikasi formal seringkali dilaksanakan dalam bentuk tertulis. Komunikasi bentuk tertulis lebih dipilih sebab memiliki keutamaan terstruktur atau sistematis, fokus dan lebih efektif. Selain itu, komunikasi tertulis lebih jelas dalam menyampaikan tujuan komunikasi. Korespondensi atau surat, sebagai bentuk dari komunikasi tertulis, memiliki fungsi dan peran penting untuk kelancaran kegiatan organisasi. Arsip korespondensi merupakan arsip yang dihasilkan dari kegiatan korespondensi atau surat menyurat. Surat menjadi media penyampai informasi berupa keputusan, pemberitahuan, pernyataan, permintaan dan sebagainya. Hal tersebut secara tidak langsung dapat mendorong organisasi untuk menciptakan tata kelola kearsipan yang baik.

Surat adalah produk yang dihasilkan dari kegiatan administrasi di suatu organisasi. Korespondensi merupakan unsur organisasi yang erat kaitannya dengan kegiatan administrasi tata usaha. Semakin besar organisasi dan semakin kompleks kegiatan didalamnya, maka intensitas tata usaha dan tulis menulis semakin tinggi pula. Kesimpulan yang diambil adalah korespondensi berbanding lurus dengan besaran ruang lingkup organisasi dan kompleksitas kegiatan organisasi. Korespondensi sudah menjadi alat komunikasi yang digunakan setiap hari dilingkungan organisasi, sehingga perbandingan tersebut berpeluang untuk menciptakan arsip korespondensi dengan jumlah yang besar.

Ada enam asas dalam korespondensi (Zulkarnain, 2015: 175), diantaranya asas keamanan, asas kecepatan dan ketepatan, asas pertanggungjawaban, asas keterkaitan, asas pembakuan serta asas efektif dan efisien. Asas-asas tersebut mendorong perlunya kegiatan pengurusan surat. Pengurusan surat adalah salah satu bentuk perhatian terhadap urgensi pengelolaan surat. Asas pertama merupakan asas keamanan, informasi yang dimuat pada korespondensi hanya dapat dibaca oleh petugas pengelola korespondensi atau pejabat yang memiliki kewenangan. Hal tersebut bertujuan menjamin keamanan informasi agar tidak disalahgunakan. Asas kedua, kecepatan dan ketepatan, yang artinya pembuatan surat dan jawaban surat harus dilakukan secepat mungkin untuk mendukung kelancaran tugas organisasi. Asas ketiga yaitu pertanggungjawaban, bahwa korespondensi harus memiliki isi, format, prosedur, kewenangan, keabsahan dan pengelolaan kearsipan yang dapat dipertanggungjawabkan. Yang keempat adalah asas keterkaitan, bahwa seluruh 
kegiatan korespondensi merupakan sebuah bagian dari tata kearsipan, sehingga korespondensi harus memiliki sebuah arsip yang disimpan. Asas pembakuan yaitu ketentuan tata persuratan harus diatur secara jelas dan tegas oleh institusi bersangkutan agar tercipta keseragaman dalam pelaksanaannya. Asas terakhir yaitu efektif dan efisien menunjukkan bahwa penyelenggaraan tata persuratan dilaksanakan secara efektif dan efisien dalam penulisan dan penggunaan bahasa.

Dinas Kearsipan dan Perpustakaan Provinsi Jawa Tengah (selanjutnya disebut Dinarpus Jateng) merupakan salah satu lembaga kearsipan tingkat provinsi yang ada di Jawa Tengah. Frekuensi kegiatan korespondensi yang cukup tinggi di Dinarpus Jateng terkadang masih memungkinkan terjadinya hal-hal yang berjalan di luar kendali Admin Dinas. Salah satu contoh permasalahan yang pernah terjadi yaitu keterlambatan surat yang disebabkan adanya miskomunikasi yang terjadi pada proses serah terima surat dari bagian resepsionis ke bagian Admin Dinas penginput surat.

Keterlambatan surat terjadi pada surat masuk yang merupakan sebuah undangan agenda kegiatan rapat dari instansi lain. Kejadian tersebut dapat diketahui setelah instansi pengirim surat menghubungi Dinarpus Jateng guna mengkonfirmasi data peserta perwakilan yang menghadiri rapat di instansi yang bersangkutan. Bagian bidang Layanan menghubungi bagian Admin Dinas penerima dan penginput surat, namun tidak juga ditemukan surat yang bersangkutan. Admin Dinas pun belum pernah menerima dan menginput dalam aplikasi e-surat. Oleh sebab itu, Kepala Dinas mengharuskan mencari pengganti guna mendelegasikan pejabat melaksanakan tanggungjawab tersebut.

Berdasarkan fenomena tersebut, dapat dipahami bahwa surat memiliki fungsi vital didalam sebuah instansi, dalam hal ini instansi kedinasan. Fungsi vital tersebut diantaranya surat merupakan media pertimbangan, media pengingat dan media pembuktian. Penjabaran dari ketiga fungsi tersebut yaitu pertama fungsi surat sebagai bahan pertimbangan. Surat menjadi dasar pertimbangan serta penilaian dalam mengambil keputusan sebelum ditentukan tindakan selanjutnya. Umumnya dasar keputusan tersebut terdapat pada surat keputusan, surat rekomendasi dan surat keterangan. Fungsi kedua yaitu sebagai media pengingat, dipahami bahwa surat menjadi dokumen bernilai guna informasi untuk masa yang akan datang, sehingga dapat membantu pengguna untuk mengingat hal yang kompleks dan berpotensi lupa. Fungsi tersebut umumnya terdapat pada surat undangan dinas, surat pemberitahuan dan surat edaran. Fungsi surat sebagai bahan bukti, bermaksud bahwa surat memiliki informasi dengan sebuah keabsahan sejak surat dibubuhi dan disahkan berdasarkan peraturan yang berlaku dilingkup instansi yang bersangkutan. Oleh sebab itu nilai keaslian dan otentisitas yang ada didalamnya memiliki kekuatan hukum serta dapat dipergunakan sebagai media kebuktian. Contoh surat yang memiliki fungsi ini adalah surat perjanjian, kerjasama, persetujuan, nota dinas, surat pernyataan dan sebagainya.

Pengolahan surat di Dinarpus Jateng bertempat di Bidang Umum Kepegawaian. Kegiatan persuratan tersebut membuat tata kelola dan sistem pengurusan surat yang digunakan di Dinarpus Jateng semakin berkembang dan terus diperbaharui. Semakin berkembangnya tata kelola tersebut berpengaruh besar dalam menunjang berbagai aktivitas pokok di lingkungan Dinarpus Jateng.

Dinarpus Jateng pun tengah aktif memanfaatkan sistem otomasi kearsipan berbasis teknologi website, salah satunya diterapkan dibidang persuratan, yaitu aplikasi e-Surat. Aplikasi e-Surat adalah hasil pengembangan serta penyesuaian secara menyeluruh dari aplikasi yang Sistem Kearsipan Dinamis (SKD). Perbedaan fitur dari kedua aplikasi tersebut, diantaranya menu Arsip Aktif Arsip By Series. Menu tersebut memuat data arsip surat berdasarkan series arsipnya. Halaman tersebut menampilkan 
jangka masa aktif arsip serta keterangan Pindah, Serah, Musnah arsip. Pada aplikasi eSurat menu tersebut tidak disertakan didalamnya.

Berdasarkan latar belakang tersebut, maka pertanyaan penelitian yang diajukan oleh penulis adalah:

1. Bagaimana pengurusan surat model hibrid dengan aplikasi e-surat di lingkungan Dinas Kearsipan dan Perpustakaan Provinsi Jawa Tengah?

2. Kendala apa yang dihadapi dalam pemanfaatan aplikasi e-surat di lingkungan Dinas Kearsipan dan Perpustakaan Provinsi Jawa Tengah?

\section{METODE PENELITIAN}

Kajian yang digunakan untuk menyusun artikel ini menggunakan metode kualitatif dengan pendekatan studi kasus, yaitu pengurusan surat di Dinas Kearsipan dan Perpustakaan Provinsi Jawa Tengah. Deskriptif analitis adalah metode yang digunakan untuk menggambarkan objek kajian yang terdapat di dalam artikel ini, yaitu mendeskripsikan dan menganalisa model pengurusan surat yang memanfaatkan aplikasi e-Surat. Data yang diolah dan digunakan sebagai bahan kajian ini dikumpulkan dengan menggunakan beberapa metode pengumpulan data, yaitu:

1. Studi pustaka, penulis menggunakan metode pengumpulan data dengan studi pustaka. Studi pustaka (Zed: 2008) diartikan sebagai serangkaian kegiatan yang bekenaan dengan metode dalam pengumpulan data pustaka, membaca dan mencatat serta mengolah bahan penelitian.

2. Observasi partisipatif, metode pengumpulan data yang kedua adalah observasi partisipatif (Yusuf: 2014) yaitu "suatu proses pengumpulan data dimana peneliti berpengalaman dalam suatu program secara mendalam mengamati tingkah laku sebagai sesuatu yang berlangsung secara alami".

3. Wawancara. Menurut Bungin (2007) wawancara merupakan "proses memperoleh keterangan untuk tujuan penelitian dengan cara tanya jawab sambil bertatap muka antara pewawancara dan informan atau orang yang diwawancarai dengan atau tanpa menggunakan pedoman wawancara".

\section{HASIL DAN PEMBAHASAN}

\section{Pengurusan Surat Masuk}

Surat masuk yang diterima oleh Subbagian Umum dan Kepegawaian berasal dari berbagai latar belakang instansi. Surat masuk dikendalikan sesuai dengan urgensi penyelesaian surat, yakni mendahulukan surat yang bersifat segera dan penting. Surat dengan karakteristik tersebut perlu didahulukan sebab memerlukan proses tindaklanjut. Selain itu juga berguna dalam menjamin informasi yang masuk terkendali sesuai prosedur yang berlaku. Pemanfaatan aplikasi e-Surat dalam pengurusan surat menjadi solusi meningkatkan efektivitas dan efisiensi pengolahan informasi. Bagan alur penerimaan surat masuk di Dinarpus Jateng dapat dicermati pada gambar 1 . 


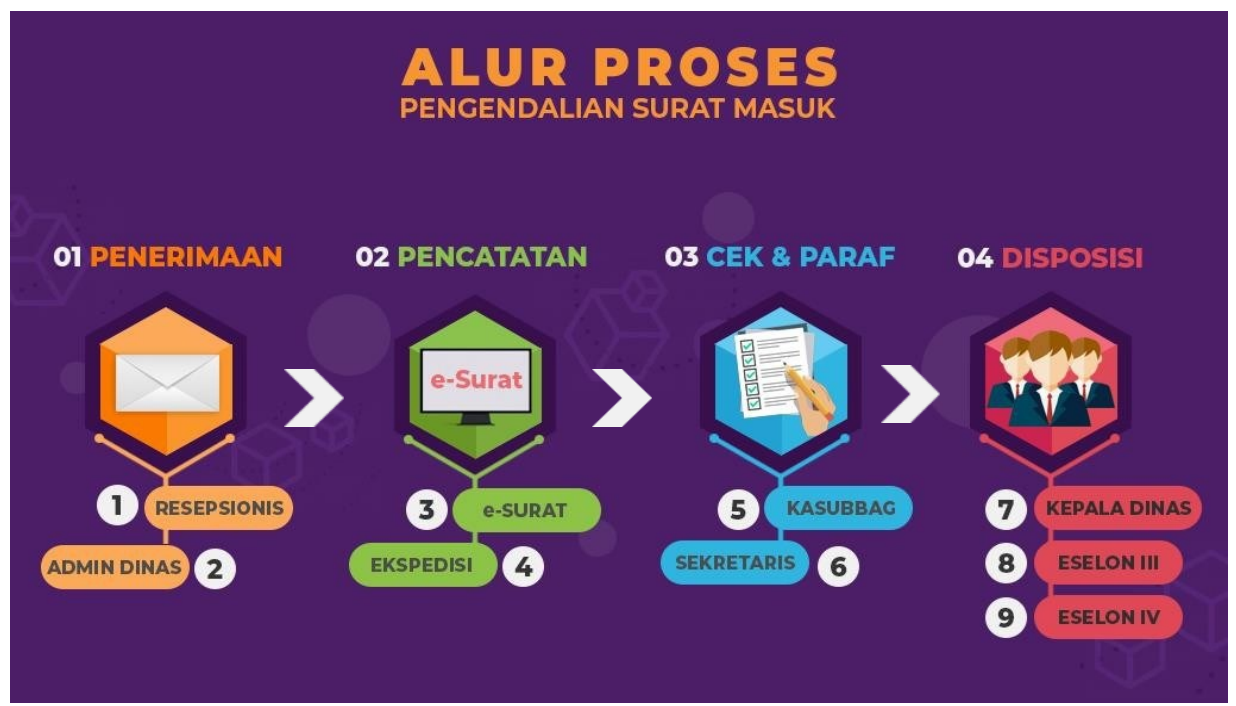

Gambar 1. Alur Proses Pengendalian Surat Masuk

\section{Keterangan:}

1. Penerimaan Surat, surat yang diproses terdapat dua bentuk, yaitu surat elektronik dan surat fisik. Surat elektronik yang masuk email resmi Dinarpus Jateng langsung dicatat kedalam aplikasi e-Surat. Adapun surat berbentuk fisik yang diterima oleh resepsionis, terlebih dahulu dicek pada bagian alamat surat, jika sudah dipastikan benar maka resepsionis mengantarkan surat tersebut ke Admin Dinas di Subbagian Umum dan Kepegawaian.

2. Pengecekan Surat, admin Dinas melakukan pengecekan pada bagian sifat surat, yaitu Biasa, Penting, Rahasia, dan Pribadi. Sifat surat umumnya tercantum pada bagian luar surat, sehingga diketahui secara oleh admin dinas tanpa harus melihat isinya. Adapun sifat surat dinas menurut urgensinya terdapat dua jenis yaitu Biasa dan Penting atau Segera. Sifat surat tersebut dapat tercantum pada bagian amlop maupun pada bagian dalam surat. Surat dengan sifat Penting atau Segera harus diprioritaskan dalam pencatatan, sebab perlu konfirmasi, balasan atau tindaklanjut dengan segera. Petugas juga memastikan kelengkapan dari surat agar tidak terpisah dan tidak tercampur dengan surat lainnya.

3. Pencatatan Surat

a. Pengisian Buku Ekspedisi, atau buku pengantar surat berfungsi sebagai bukti register adanya serah terima surat ke bidang lain. Buku ekspedisi mencatat tanggal dan nomor urut surat yang diserahkan kepada sekretariat pada saat penyerahan surat. Penggunaan buku tersebut mencegah adanya hal-hal yang tidak diinginkan, seperti lalai dalam menyerahkan surat, surat tertinggal dan sebagainya;

b. Pencatatan Berbasis Aplikasi e-Surat, aplikasi e-Surat telah tersedia menu Surat Masuk. Surat Masuk merupakan salah satu fitur utama yang dapat diakses melalui akun Admin Dinas. Terdapat beberapa menu utama disisi kiri layar dan beberapa fitur statistik dibagian tengah untuk memonitor jumlah surat masuk dan surat keluar; 


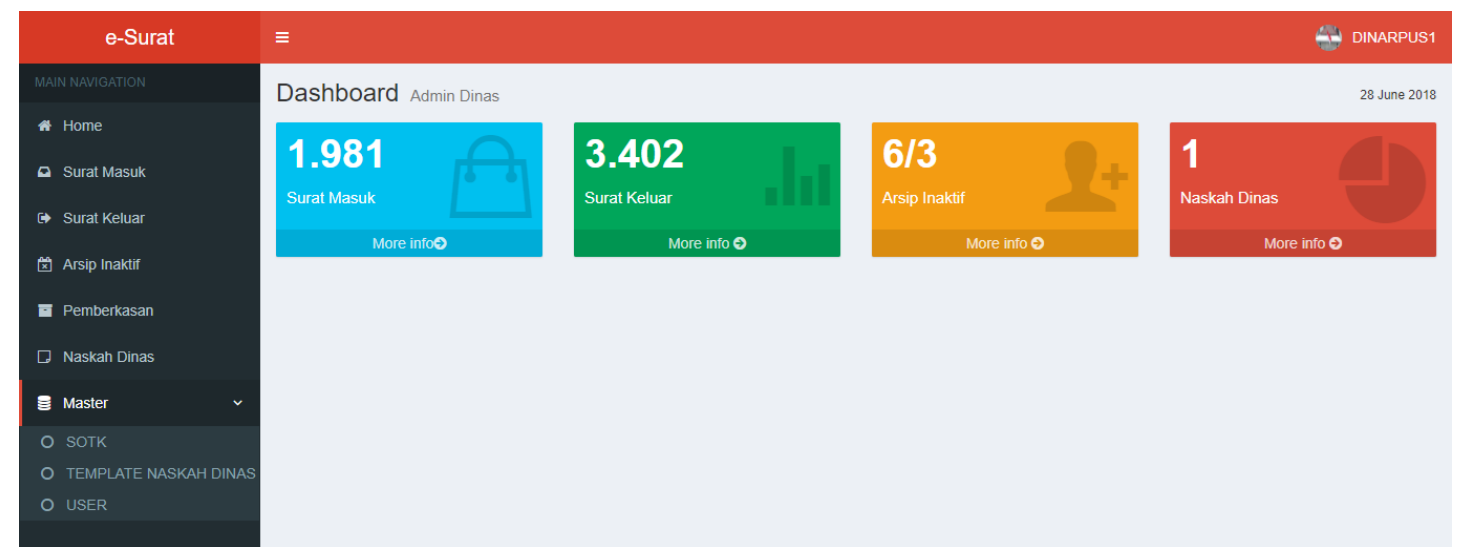

Gambar 2. Halaman Beranda Aplikasi e-Surat

Menu bagian sisi layar diantaranya: Home/Beranda, Surat Masuk, Surat Keluar, Arsip Inaktif, Pemberkasan, Naskah Dinas, Master. Pada menu Master terdapat submenu SOTK, Templat Naskah Dinas, dan User. Menu Surat Masuk dan Surat Keluar fungsinya untuk mengelola surat masuk dan surat keluar. Arsip Inaktif untuk pengelolaan arsip inaktif. Menu pemberkasan untuk pengelolaan pemberkasan surat masuk dan surat keluar. Menu naskah dinas digunakan untuk membuat draft naskah dinas sesuai tata naskah dinas. Dalam submenu master, menu SOTK berisi susunan organisasai tata kerja. Templat tata naskah dinas berisi kumpulan konsep dan tata letak tata naskah dinas. Adapun menu user berisi data pejabat struktural dan admin dinas yang memiliki akses dalam aplikasi e-Surat. Ketujuh menu tersebut hanya dua menu yang aktif digunakan dalam kegiatan pengurusan surat, yaitu menu Surat Masuk dan Surat Keluar. Menu surat masuk menyediakan berbagai fitur pokok pengurusan surat. Admin Dinas dapat melaksanakan kegiatan pengurusan surat mulai dari pencatatan identitas surat, isi surat, klasifikasi hingga meneruskan surat pada bidang sekretariat.

Halaman pengolahan surat masuk terdapat beberapa tombol fungsi dan kolom data yang menampilkan rincian surat masuk. Kolom rincian data surat masuk memuat nomor urut, tombol fungsi cetak, nomor urut surat, tanggal, nomor surat, asal surat, isi surat dan user ID operator. Surat yang diterima dan telah diperiksa sifat serta kelengkapannya, dapat dilanjutkan dengan input data kedalam aplikasi e-Surat.

Aplikasi e-Surat menampilkan identitas surat yang meliputi instansi pengirim surat, tanggal surat diterima, tanggal surat dibuat, tanggal surat diteruskan, penerima meneruskan surat, prioritas surat (reguler dan perioritas tinggi), catatan tambahan jika diperlukan, nomor urut surat masuk, nomor surat, perihal surat, kode klasifikasi, isi ringkasan surat, indeks atau kata kunci, nilai guna surat (administrasi, hukum, keuangan dan IPTEK), bentuk media yang diterima (dokumen, audio, video, elektronik dan tekstual), tingkat perkembangan (asli, tembusan, salinan/ganda, fotocopy dan pertinggal), jumlah lampiran (berkas dan bendel), serta copy digital surat.

e-Surat menyediakan daftar seluruh Organisasi Pemerintah Daerah (OPD) di Jawa Tengah. Hal ini karena mayoritas surat berasal dari lingkungan OPD. Apabila surat berasal dari selain OPD, pengguna mengetikkan asal surat secara manual. Penerusan surat diisikan dengan menyesuaikan pada kategori isi 
surat. Pemilihan SOTK harus cermat, agar surat diterima tepat sasaran oleh Satuan Organisasi Tata Kerja di lingkungan Dinarpus Jateng. Setelah semua data diinput, dengan menekan tombol Tambah Data maka seluruh data tersebut akan langsung tersimpan dalam server e-Surat. Pengurusan surat masuk dengan e-Surat diakhiri mencetak satu lembar disposisi dan tiga lembar kartu kendali menggunakan kertas berwarna merah, putih dan kuning. Data tersebut dapat dihapus atau diubah untuk diperbarui apabila Admin Dinas melakukan kesalahan dalam penginputan.

c. Paraf Kasubag, sebelum diserahkan ke Kepala Dinas untuk disposisi ke Eselon III, petugas membawanya ke Kepala Subbagian Umum dan Kepegawaian untuk diperiksa dan diberikan paraf.

4. Disposisi Surat, lembar disposisi kosong yang telah diberikan paraf oleh Kasubbag diantarkan ke bagian Sekretariat beserta dengan buku ekspedisi untuk diteliti lagi dan diberikan paraf oleh sekretaris. Surat tersebut kemudian diantarkan ke Kepala Dinas untuk diberikan disposisi melalui aplikasi e-Surat. Disposisi yang diberikan dari Kepala Dinas ditujukan kepada pejabat di tingkat Eselon III yaitu Sekretaris, Kepala Bidang, dan UPT. Pejabat Eselon III yang menerima disposisi kemudian mendisposisi kembali surat tersebut kepada Pejabat Eselon IV yaitu Kepala Seksi dan Kepala Subbagian. Pejabat Eselon IV akan melaksanakan instruksi yang sesuai dengan isi surat.

\section{Pengurusan Surat Keluar}

Surat keluar bermaksud seluruh surat yang dibuat dan dikirimkan dari unit ke unit di internal organisasi maupun antar organisasi. Surat keluar yang dibuat untuk internal organisasi dapat berupa laporan, surat perintah atau sejenisnya. Adapun surat keluar antar organisasi mencakup lebih banyak jenis surat keluar, seperti undangan, surat balasan, permohonan dan sebagainya. Pengurusan surat keluar dilakukan untuk memastikan surat dikirimkan sesuai kaidah aturan surat dinas. Selain itu pengurusan surat juga berguna memudahkan dalam proses temu kembali. Adanya kemudahan tersebut dapat meminimalisir hal-hal yang dapat menghambat kinerja organisasi.

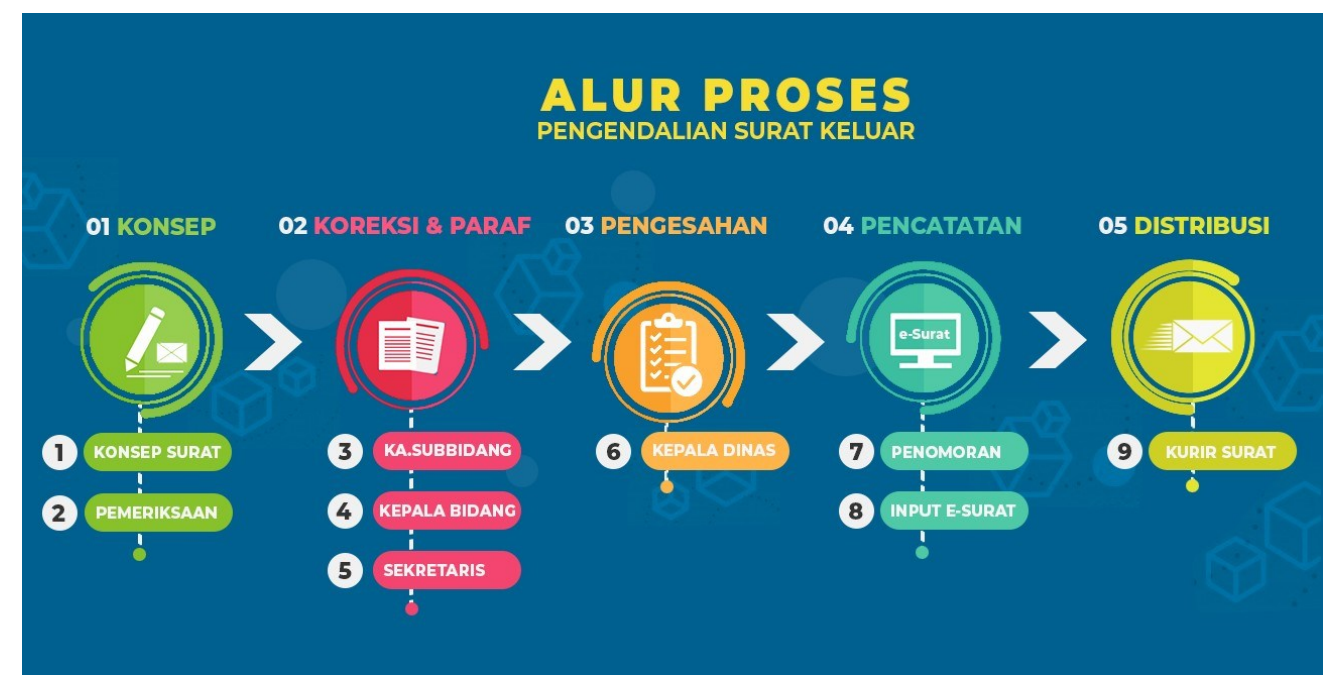

Gambar 4. Alur Proses Pengendalian Surat Keluar 


\section{Keterangan:}

1. Pembuatan Konsep Surat, dibuat oleh unit pencipta surat dinas yang ada di masing-masing bidang. Hal tersebut menyesuaikan format dengan kebutuhan masing-masing. Pembuatan konsep surat masih secara manual. Aplikasi e-Surat memiliki menu Templat Naskah Dinas yang memudahkan pengguna untuk membuat surat dinas keluar sesuai dengan keperluan. Akan tetapi fitur tersebut masih terdapat kendala, yaitu terkait peraturan yang belum terbentuk dan belum berfungsinya menu tersebut secara normal. Cara manual dengan mengedit surat yang serupa dipilih sebagai upaya untuk menjaga agar konsep surat tidak berubah. Daftar konsep surat yang terdapat dalam aplikasi e-Surat dapat dicermati pada gambar 5 .

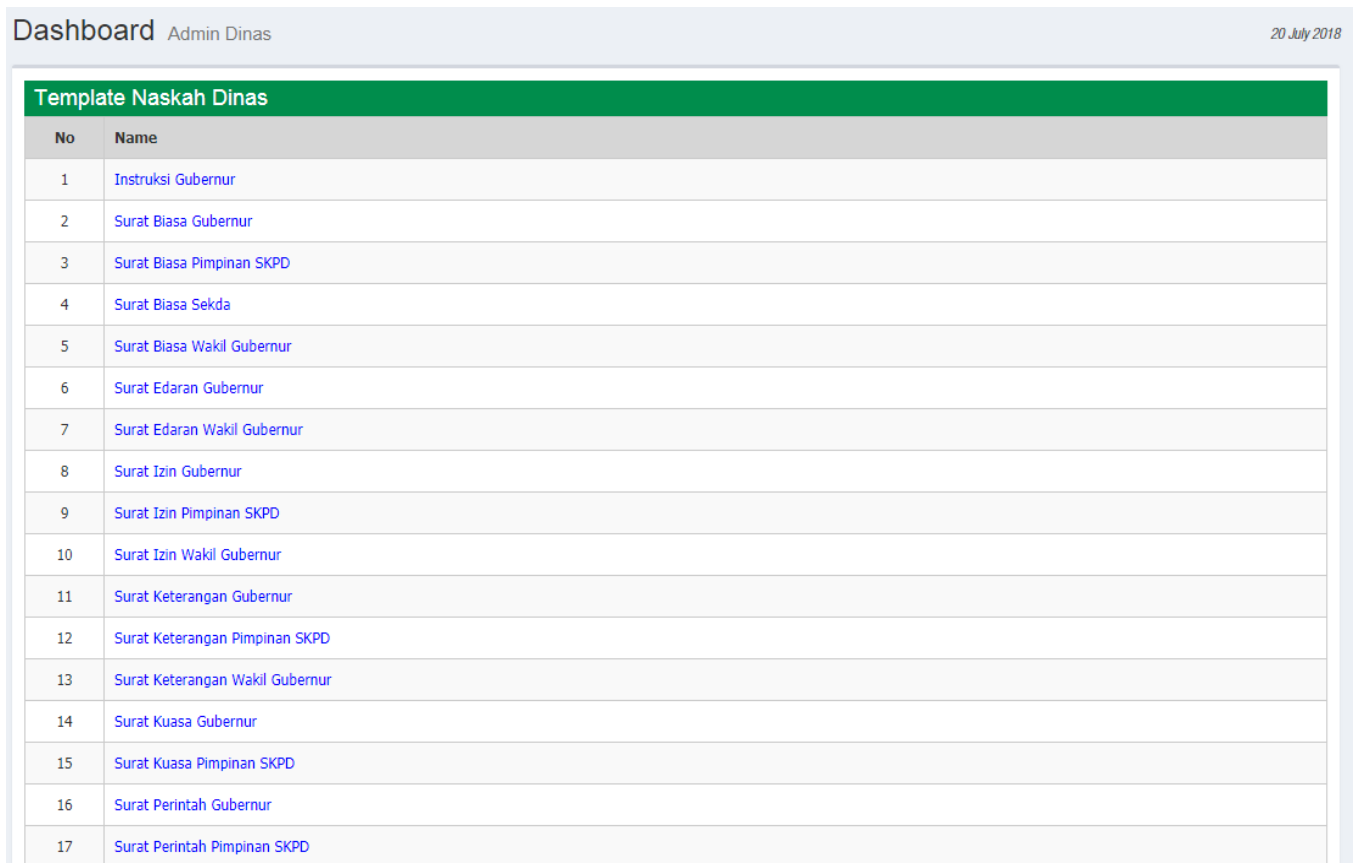

Gambar 5. Menu Template Naskah Dinas e-Surat

2. Koreksi dan Paraf, surat yang telah dipastikan kelengkapan dan tidak terdapat kesalahan format maupun kalimat dan isi, diberikan paraf dari Kepala Sub Bidang dan Kepala Bidang. Setelah itu selanjutnya diajukan ke bagian Sekretariat. Surat tersebut dicatat dalam buku agenda milik sekretariat, diberikan tanda tangan kepala dinas.

3. Penomoran Surat, dilakukan dengan melihat urutan nomor surat yang terdapat pada aplikasi e-Surat. Setelah konsep suratselesai disahkan, unit pencipta naskah dinas membawa surat ke petugas pengurusan surat untuk dimintakan nomor surat. Nomor surat terdiri dari kode klasifikasi dan nomor urut surat. Kode klasifikasi mengacu pada Peraturan Gubernur Provinsi Jawa Tengah nomor 53 tahun 2012. Nomor surat telah tersedia sesuai urutan di aplikasi e-Surat. Penomoran yang pendek memudahkan untuk proses temu kembali. Penomoran surat dilakukan dengan terlebih dahulu memperhatikan tanggal pembuatan surat. Oleh sebab tidak semua surat dibuat pada hari yang sama dengan hari pengiriman, maka Admin Dinas memberi jeda 15 nomor setiap harinya. Hal tersebut sebagai antisipasi adanya susulan surat yang pengirimannya berbeda dengan tanggal pembuatan surat. Untuk mengetahui nomor yang ada dapat dilakukan dengan membuka halaman data surat keluar. Penomoran dilakukan dengan memperhatikan kolom tanggal dan kolom nomor urut (kolom bertanda 


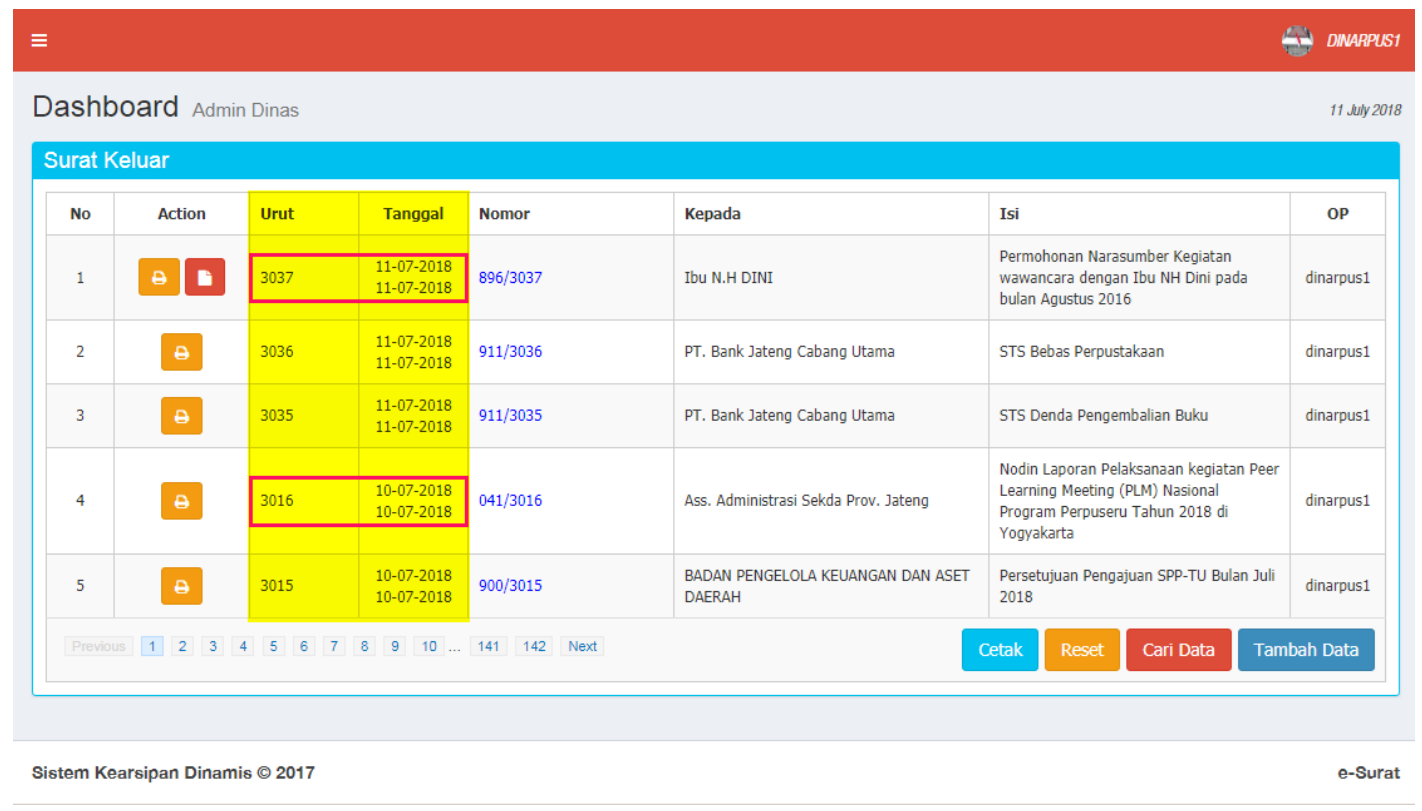

Gambar 6. Halaman Data Surat Keluar

kuning). Contoh penomoran: apabila surat dibuat tanggal 11 Juli 2018 maka surat tersebut mendapatkan nomor urut 3038, sedangkan jika terdapat surat susulan yang dibuat pada tanggal 10 Juli 2018, maka surat tersebut akan diberikan nomor urut sesuai slot nomor yang masih kosong di tanggal 10 Juli setelah nomor 3016, yaitu nomor urut 3017. Setelah diketahui penomoran yang sesuai, dilanjutkan dengan input data surat keluar melalui tombol Tambah Data.

4. Pencatatan dengan Menggunakan Aplikasi e-Surat, fitur menu Surat Keluar tidak jauh berbeda dengan menu Surat Masuk. Data yang harus di input dalam pengurusan surat keluar diantaranya: instansi penerima surat, tanggal surat dibuat, tanggal surat dikirim, nomor urut surat sesuai aplikasi, nomor surat, perihal surat, kode klasifikasi surat, isi surat, indeks atau kata kunci, unit pengolah, nilai guna, bentuk media, jenis tingkat perkembangan, jumlah lampiran dan copy digital surat. Perbedaan antara input surat keluar dengan surat masuk adalah bagian kolom pengisian data yang lebih sedikit. Halaman input surat keluar tidak terdapat kolom untuk tanggal surat diteruskan, kolom forwarding, kolom urgensi atau prioritas surat dan kolom catatan, tetapi pada surat keluar terdapat tambahan kolom untuk unit pengolah surat keluar. Selain yang disebutkan tersebut adalah sama dengan pengisian data surat masuk. Penginputan data yang telah selesai, dilanjutkan dengan mencetak lembar kartu kendali.

\section{Pengurusan Surat Model Hibrid dengan Memanfaatkan Aplikasi e-Surat}

Aplikasi e-Surat adalah aplikasi pengurusan surat berbasis website yang digunakan untuk mengolah surat masuk dan surat keluar di lingkungan Dinas Kearsipan dan Perpustakaan Provinsi Jawa Tengah. Aplikasi tersebut dibangun untuk memudahkan pengguna dalam tata kelola administrasi pemerintahan terutama dalam pengurusan surat. Keberadaan aplikasi tersebut menjadi solusi atas tantangan perubahan zaman. Selain itu juga menjadi upaya memenuhi tuntutan kinerja organisasi publik untuk mengusung pelayanan yang efektif, efisien dan akuntabel. Langkah Dinarpus Jateng mengupayakan terciptanya pengelolaan arsip dinamis berbasis eletronik diharapkan memberikan dampak luas dalam perkembangan teknologi 
kearsipan. Namun tetap memperhatikan kaidah-kaidah ilmu kearsipan agar terdapat keseragaman dalam teori dan praktik.

Aplikasi e-Surat yang dikembangkan Dinarpus Jateng merupakan jenis aplikasi berbasis website yang dijalankan secara online. Hal tersebut berfungsi dalam menunjang mobilitias pengguna untuk dapat mengakses e-Surat kapan pun dan dimana pun. Alamat website e-Surat Dinarpus Jateng berada dalam domain utama yang dikelola oleh Pemerintah Provinsi Jawa Tengah, yaitu https://jatengprov.go.id. Penggunaan aplikasi tersebut dalam pengurusan surat di Dinarpus Jateng terlihat pada saat input surat masuk dan input surat keluar.

Tabel 1. Pengurusan Surat Masuk Model Hibrid di Dinarpus Jateng

\begin{tabular}{llll}
\hline No & Tahapan pengurusan surat Masuk & Konvensional & e-Surat \\
\hline 1. & Penerimaan & $\sqrt{ }$ & \\
2. & Pengecekan Surat & $\sqrt{ }$ & $\sqrt{ }$ \\
3. & Pencatatan Surat & $\sqrt{ }$ & $\sqrt{ }$ \\
4. & Disposisi Surat & $\sqrt{ }$ & \\
\hline
\end{tabular}

Pemanfaatan aplikasi untuk proses pengurusan surat masuk berada pada tahapan pencatatan dan disposisi aktivitas. Hal tersebut menunjukkan penggunaan e-Surat dilakukan bersama dengan aktivitas konvensional. Pada pengurusan surat keluar menggunakan aplikasi, fitur yang digunakan adalah fitur surat keluar. Penggunaan aplikasi juga terdapat pada pengurusan surat keluar. Pemanfaatan aplikasi untuk proses pengurusan surat keluar cukup mendominasi yaitu 3 aktivitas dari rangkaian aktivitas pengurusan surat keluar. Hal tersebut menunjukkan bahwa penggunaan eSurat dilakukan bersama dengan aktivitas konvensional.

Tabel 2. Pengurusan Surat Keluar Model Hibrid di Dinarpus Jateng

\begin{tabular}{llll}
\hline No & Tahapan pengurusan surat Keluar & Konvensional & e-Surat \\
\hline 1. & Pembuatan Konsep & $\sqrt{ }$ \\
2. & Koreksi dan Penandatanganan & $\sqrt{ }$ & $\sqrt{ }$ \\
3. & Penomoran Surat & $\sqrt{ }$ \\
4. & Pencatatan Surat & \\
\hline
\end{tabular}

\section{KESIMPULAN}

Aplikasi e-Surat adalah aplikasi berbasis website yang mendukung mobilitas dalam pemanfaatan pengelolaan korespondensi di Dinas Perpustakaan dan Kearsipan Provinsi Jawa Tengah. Dinas memanfaatkan aplikasi berbasis website sejak 2011 dengan nama aplikasi SIKD (Sistem Informasi Kearsipan Dinamis). Aplikasi baru digunakan mulai bulan Desember tahun 2017 setelah analisis kebutuhan pengelolaan surat secara elektronik. Dinarpus Jateng menjadikan aplikasi e-Surat sebagai pengganti aplikasi SIKD yang kurang sesuai dengan kebutuhan pengurusan surat di lingkungan Dinas Kearsipan dan Perpustakaan Provinsi Jawa Tengah. 
Aplikasi e-Surat pada kegiatan pengurusan surat masuk digunakan menginput data surat, mencetak lembar kartu kendali dan disposisi kosong serta digunakan untuk memudahkan proses temu kembali surat, sedangkan dalam pengurusan surat keluar, aplikasi e-Surat digunakan untuk penentuan nomor surat dan disposisi oleh pejabat struktural dan fungsional. Sistem penomoran surat terdiri dari dua jenis nomor, yaitu kode klasifikasi surat dan nomor urut surat dalam aplikasi.

Keberadaan aplikasi tersebut di Dinarpus Jateng dalam menunjang komunikasi organisasi memberikan dampak yang positif. Model komunikasi dalam dilakukan secara formal melalui media surat, terfasilitasi oleh adanya aplikasi e-Surat. Pemanfaatan aplikasi e-Surat dalam komunikasi organisasi lebih mendominasi pada model komunikasi downward. Kegiatan pengurusan surat masuk merupakan salah satu bagian dari bentuk komunikasi downward. Hal tersebut disebabkan dalam kegiatan pengurusan surat masuk terdapat serangkaian kegiatan yang menunjukkan pola komunikasi dari pimpinan kepada bawahan.

Model komunikasi downward pengurusan surat ada di kegiatan pendisposisian surat, yaitu pemberian petunjuk atau perintah singkat yang diberikan oleh Kepala Dinas kepada pejabat dibawahnya mengenai tindaklanjut surat. Rangkaian panjang tersebut dapat dilakukan dengan waktu yang lebih singkat melalui aplikasi e-Surat, sedangkan pemanfaatan aplikasi e-Surat dalam model komunikasi upward belum sepenuhnya termanfaatkan. Hal ini karena beberapa fitur masih dalam tahap pengembangan oleh Dinarpus Jateng.

Aplikasi e-Surat yang menjadi fasilitas pokok komunikasi yang efektif dan efisien di lingkungan organisasi. Beberapa kendala yang ditemukan dalam aplikasi tersebut merupakan kendala yang bersifat teknis. Sebagian fitur yang disematkan dalam aplikasi pun belum sepenuhnya digunakan secara maksimal. Analisa perlu dilakukan oleh tim pengembang dan pengguna aplikasi e- Surat agar pemanfaatan fitur dan fungsinya dapat di maksimalkan.

\section{DAFTAR PUSTAKA}

Yusuf, A. Muri. 2014. Metode Penelitian : Kuantitatif, Kualitatif \& Penelitian Gabungan. Jakarta: Kencana.

Widjaja, A.W. 1986. Administrasi Kearsipan. Jakarta: Rajawali.

Martono, Boedi. 1992. Pengurusan Surat. Jakarta: ANRI.

Bungin, Burhan. 2007. Penelitian Kualtatif: Komunikasi, Ekonomi, Kebijakan Publik dan Ilmu Sosial Lainnya. Jakarta: Kencana.

Dinas Kearsipan dan Perpustakaan Provinsi Jawa Tengah, Manual Aplikasi Kearsipan Dinamis (e-Surat), 2017.

Graber, Doris A. 2003. The Power of Communication: Managing Information in Public Organizations. Washington DC: CQ Press.

Ellen Guffey, Marry. dkk., . 2010. Business Communication: Process and Product. Toronto: Nelson Education. Ltd.

Information Resources Management Association. 2018. Social Issues in the Workplace: Breakthroughs in Research and Practice. USA: IGI Global.

Keyton, Joann. 2005. Communication \& Organizational Culture: A Key to Understanding Work Experiences. California: SAGE Publication.

Turner, Lyn H. 2008. Pengantar Teori Komunikasi 7. Jakarta: Salemba Humanika. 
Zed, Mestika. 2008. Metode Penelitian Kepustakaan. Jakarta: Yayasan Obor Indonesia. Musliichah. 2017. Bunga Rampai Kearsipan. Yogyakarta: Gadjah Mada University Press. S. Susanto, Phill Astrid. 1974. Komunikasi Dalam Teori dan Praktek. Jakarta: Binacipta. Peraturan Kepala ANRI nomor 33 tahun 2012, Pedoman Pengurusan Surat di Lingkungan Arsip Nasional Republik Indonesia, (Jakarta: ANRI, 2012)

Daft, Richard L. 2012. Management - Tenth Edition. USA: Cengage Learning.

Tandon, B.N. 1982. Manual of OfGice Management and Correspondence. ---: S. Chand \& Company LTD.

The Institute if Internal Auditors on www.theiia.org, Suplemental Guidance: Public Sector Definition, (USA: Global Headquarters, 2011).

Zulkarnain, Wildan. 2015. Manajemen Perkantoran Profesional. Malang: Penerbit Gunung Samudera. 